\title{
Determination of Bond index of Birnin- Gwari Iron Ore in Nigeria
}

\section{K.J. Olatunji* and A.G. Durojaiye}

\author{
Mineral Resources Engineering Department, Kwara State Polytechnic, Ilorin, Nigeria \\ *Corresponding Author: tunjikay2005@gmail.com
}

\begin{abstract}
Bond index is useful in designing of grinding system in mineral processing. In this study, the Bond work index of Birnin-Gwari iron ore in northern Nigeria is determined using modified Bond's method using 'reference ore'. Samples of iron ore were sourced using random method, reference minerals; marble and granite of known weight and iron ore of known weight were ground using the laboratory ball mill grinding machine. $80 \%$ passing size for the iron ore marble and granite samples were obtained at $100 \mu \mathrm{m}$ sieve size for the feeds and products. The work index of reference minerals; marble and granite were used to calculate the work index of iron ore. The value of $28.66 \mathrm{Kwh} /$ short ton and $24.92 \mathrm{Kwh} /$ short ton were obtained. The value of $20.39 \mathrm{Kwh} / \mathrm{short}$ ton was selected as it is within the range indicated by previous research work on iron ore in Nigeria.
\end{abstract}

Keywords: Bond index, Birnin-Gwari iron ore, modified, reference minerals, mineral processing.

\section{INTRODUCTION}

Iron ore deposits are usually present as iron oxides (magnetite, $\mathrm{Fe}_{3} \mathrm{O}_{4}$; haematite, $\mathrm{Fe}_{2} \mathrm{O}_{3}$ ), hydroxides (geotite, $\mathrm{FeO}(\mathrm{OH})$ ), limonite, $2 \mathrm{Fe}_{2} \mathrm{O}_{3} \cdot \mathrm{H}_{2} \mathrm{O}$ and carbonates (siderite, $\mathrm{FeCO}_{3}$ ). Nigeria has a lot of iron ore deposits in different locations around the country with their respective proven and unproven reserves. (Geological Survey of Nigeria, 1980; Battey, 1981).

Communition in mineral processing plant or mill takes place as a sequence of crushing and grinding processes. Crushing reduces the particle size of run-off-mine ore to such a level that grinding can be carried out until the mineral and gauges are substantially produced as separated particles (Wills, 2006). 
The most widely used parameter to measure ore grindability is the Bond work index, Wi (Magdalimovic,1989). Numerically the work index is the energy required in Kwh/short ton to reduce a given material from theoretically infinite size to $80 \%$ passing size of 100 microns (Onemine, 2009).

The determination of work index using modified Bond's method can be compared to method of determining it by Berry and Bruce (1966). This method requires the use of a reference ore of known grindability.

The objective of this study is to determine the grindability of Birnin-Gwari iron ore in Northern Nigeria using the modified Bond's method.

\section{MATERIALS AND METHODS}

Samples of iron ore were obtained from Birnin-Gwari iron ore deposit hill, marble from Igbetti and granite from Ilorin using random sampling method. The samples were collected at various spot, $5 \mathrm{~m}$ apart. $20 \mathrm{~kg}$ of each mineral was obtained for the study.

The samples were broken manually with a sledge hammer to provide the required size acceptable to laboratory jaw crusher. The samples were crushed and pulverized, part of pulverized samples were weighed for sieve analysis. The modified Bond's method of determining the net work index of ore involves use of reference ore of which grindability is known. The procedure is as follows.

1. $100 \mathrm{~g}$ each of samples of the ore under test and the reference ore are crushed and pulverized in the laboratory mill machine for an hour,

2. The samples of test and reference ores were taken and sized by sieving into a number of size fraction using the automatic sieve shaker for 15 minutes.

3. Each size fraction of the test and the reference ores were weighed and the value noted "feed".

4. The "feed " test and reference ores were each gathered together and introduced into the laboratory mill machine and ground for 15 minutes.

5. The test and the reference ores from the laboratory ball mill machine were sized and each sieve fractions was weighed and the value noted as the product or discharge.

6. Sieve analysis.

The ground samples were sieved into the following sieve size fractions; $+365 \mu \mathrm{m},-355$

$\mu \mathrm{m},+250 \mu \mathrm{m},-250 \mu \mathrm{m},+180 \mu \mathrm{m},-180 \mu \mathrm{m},+125 \mu \mathrm{m},-125 \mu \mathrm{m},+90 \mu \mathrm{m},-90 \mu \mathrm{m},+63$

$\mu \mathrm{m},-63 \mu \mathrm{m}$ using automatic sieve shaker for 15 minutes. 


\section{RESULT AND DISCUSSION}

Table 1 below shows the sieve analysis result of the feed to ball mill of reference mineral (marble).

Table 1: The feed to ball mill of reference mineral (marble).

\begin{tabular}{|l|l|l|l|l|}
\hline $\begin{array}{l}\text { Sieve size } \\
\text { range }(\mu \mathrm{m})\end{array}$ & $\begin{array}{l}\text { Weight retained } \\
(\mathrm{g})\end{array}$ & $\begin{array}{l}\text { \% Weight } \\
\text { retained }\end{array}$ & $\begin{array}{l}\text { Cumulative \% } \\
\text { weight retain }\end{array}$ & $\begin{array}{l}\text { Cumulative \% } \\
\text { weight passing }\end{array}$ \\
\hline+355 & 2.04 & 2.04 & 2.04 & 97.96 \\
\hline$-355-+250$ & 1.74 & 1.74 & 3.78 & 96.22 \\
\hline$-250-+180$ & 1.94 & 1.94 & 5.72 & 94.28 \\
\hline$-180-+125$ & 20.94 & 20.94 & 26.66 & 73.34 \\
\hline$-125-+90$ & 21.40 & 21.40 & 48.06 & 51.44 \\
\hline$-90-+63$ & 25.04 & 25.04 & 73.1 & 26.90 \\
\hline-63 & 26.90 & 26.90 & 100 & 0.00 \\
\hline
\end{tabular}

Calculation 1:

If $125(\mu \mathrm{m})=73.34 \%$

$\mathrm{x}(\mu \mathrm{m}) \quad=80 \%$

$x=\underline{80 \times 125}$

73.34

$=136.35 \mu \mathrm{m}$ at $80 \%$

Table 2 below shows the sieve analysis result of the feed of reference mineral (granite) to the ball mill.

Table2: The feed of reference mineral (granite) to the ball mill.

\begin{tabular}{|l|l|l|l|l|}
\hline $\begin{array}{l}\text { Sieve size } \\
\text { range }(\mu \mathrm{m})\end{array}$ & $\begin{array}{l}\text { Weight retained } \\
(\mathrm{g})\end{array}$ & $\begin{array}{l}\text { \% Weight } \\
\text { retained }\end{array}$ & $\begin{array}{l}\text { Cumulative \% } \\
\text { weight retain }\end{array}$ & $\begin{array}{l}\text { Cumulative \% } \\
\text { weight passing }\end{array}$ \\
\hline+355 & 3.94 & 3.90 & 3.90 & 96.66 \\
\hline$-355-+250$ & 3.68 & 3.68 & 7.58 & 92.42 \\
\hline$-250-+180$ & 3.94 & 3.94 & 11.52 & 88.48 \\
\hline$-180-+125$ & 3.64 & 3.64 & 15.16 & 84.84 \\
\hline$-125-+90$ & 5.44 & 5.44 & 20.6 & 79.4 \\
\hline$-90-+63$ & 26.94 & 26.94 & 47.54 & 52.46 \\
\hline-63 & 52.46 & 52.46 & 100 & 0.00 \\
\hline
\end{tabular}


Calculation 2:

If $125(\mu \mathrm{m})=84.84 \%$

$\mathrm{x}(\mu \mathrm{m}) \quad=80 \%$

$x=\underline{80 \times 125}$

84.84

$=117.9 \mu \mathrm{m}$ at $80 \%$

Table 3 below shows the sieve analysis of the feed of test ore to Ball mill.

Table 3: The feed of test ore to Ball mill.

\begin{tabular}{|l|l|l|l|l|}
\hline $\begin{array}{l}\text { Sieve size } \\
\text { range }(\mu \mathrm{m})\end{array}$ & $\begin{array}{l}\text { Weight retained } \\
(\mathrm{g})\end{array}$ & $\begin{array}{l}\text { \% Weight } \\
\text { retained }\end{array}$ & $\begin{array}{l}\text { Cumulative \% } \\
\text { weight retain }\end{array}$ & $\begin{array}{l}\text { Cumulative \% } \\
\text { weight passing }\end{array}$ \\
\hline+355 & 2.65 & 2.65 & 2.65 & 97.35 \\
\hline$-355-+250$ & 2.53 & 2.53 & 5.20 & 94.80 \\
\hline$-250-+180$ & 2.45 & 2.45 & 7.65 & 92.35 \\
\hline$-180-+125$ & 2.45 & 2.45 & 10.10 & 89.90 \\
\hline$-125-+90$ & 27.46 & 27.46 & 37.56 & 62.44 \\
\hline$-90-+63$ & 36.94 & 36.94 & 74.5 & 25.5 \\
\hline-63 & 25.5 & 25.5 & 100 & 0.00 \\
\hline
\end{tabular}

Calculation 3:

If $125(\mu \mathrm{m})=89.90 \%$

$\mathrm{x}(\mu \mathrm{m}) \quad=80 \%$

$\mathrm{x}=\underline{80 \times 125}$

89.90

$=111.23 \mu \mathrm{m}$ at $80 \%$

Table 4 below shows the sieve analysis of the product of reference material in the ball mill. 
Table 4 : The product of reference material (marble) in the ball mill.

\begin{tabular}{|l|l|l|l|l|}
\hline $\begin{array}{l}\text { Sieve size } \\
\text { range }(\mu \mathrm{m})\end{array}$ & $\begin{array}{l}\text { Weight retained } \\
(\mathrm{g})\end{array}$ & $\begin{array}{l}\text { \% Weight } \\
\text { retained }\end{array}$ & $\begin{array}{l}\text { Cumulative \% } \\
\text { weight retain }\end{array}$ & $\begin{array}{l}\text { Cumulative \% } \\
\text { weight passing }\end{array}$ \\
\hline+355 & 1.8 & 1.8 & 1.8 & 98.2 \\
\hline$-355-+250$ & 1.2 & 1.2 & 3.0 & 97.0 \\
\hline$-250-+180$ & 2.0 & 2.0 & 5.0 & 95.5 \\
\hline$-180-+125$ & 5.5 & 5.5 & 10.5 & 89.5 \\
\hline$-125-+90$ & 28.63 & 28.63 & 39.13 & 60.89 \\
\hline$-90-+63$ & 37.83 & 37.83 & 76.96 & 23.04 \\
\hline-63 & 23.04 & 23.04 & 100 & 0.00 \\
\hline
\end{tabular}

Calculation 4:

If $125(\mu \mathrm{m})=89.5 \%$

$\mathrm{x}(\mu \mathrm{m}) \quad=80 \%$

$\mathrm{x}=\underline{80 \times 125}$

89.5

$=111.73 \mu \mathrm{m}$ at $80 \%$

Table 5 below shows the sieve analysis of the product of reference material (granite) of ball mill.

Table 5 : The product of reference material (granite) of ball mill.

\begin{tabular}{|l|l|l|l|l|}
\hline $\begin{array}{l}\text { Sieve size } \\
\text { range }(\mu \mathrm{m})\end{array}$ & $\begin{array}{l}\text { Weight retained } \\
(\mathrm{g})\end{array}$ & $\begin{array}{l}\text { \% Weight } \\
\text { retained }\end{array}$ & $\begin{array}{l}\text { Cumulative \% } \\
\text { weight retain }\end{array}$ & $\begin{array}{l}\text { Cumulative \% } \\
\text { weight passing }\end{array}$ \\
\hline+355 & 0.1 & 0.1 & 0.1 & 99.9 \\
\hline$-355-+250$ & 0.0 & 0.0 & 0.1 & 99.9 \\
\hline$-250-+180$ & 0.1 & 0.1 & 0.2 & 99.8 \\
\hline$-180-+125$ & 3.2 & 3.2 & 3.4 & 96.6 \\
\hline$-125-+90$ & 13.1 & 13.1 & 16.5 & 83.5 \\
\hline$-90-+63$ & 27.4 & 27.4 & 43.9 & 56.1 \\
\hline-63 & 56.1 & 56.1 & 100 & 0.00 \\
\hline
\end{tabular}


Calculation 5:

If $125(\mu \mathrm{m})=83.5 \%$

$\mathrm{x}(\mu \mathrm{m}) \quad=80 \%$

$x=\underline{80 \times 125}$

96.6

$=103.52 \mu \mathrm{m}$ at $80 \%$

Table 6 below shows the sieve analysis of the product of Test ore of the ball mill.

Table 6 : The product of Test ore of the ball mill.

\begin{tabular}{|l|l|l|l|l|}
\hline $\begin{array}{l}\text { Sieve size } \\
\text { range }(\mu \mathrm{m})\end{array}$ & $\begin{array}{l}\text { Weight retained } \\
(\mathrm{g})\end{array}$ & $\begin{array}{l}\text { \% Weight } \\
\text { retained }\end{array}$ & $\begin{array}{l}\text { Cumulative \% } \\
\text { weight retain }\end{array}$ & $\begin{array}{l}\text { Cumulative \% } \\
\text { weight passing }\end{array}$ \\
\hline+355 & 0.0 & 0.0 & 0.0 & 100 \\
\hline$-355-+250$ & 0.0 & 0.0 & 0.0 & 100 \\
\hline$-250-+180$ & 0.1 & 0.1 & 0.1 & 99.99 \\
\hline$-180-+125$ & 1.1 & 1.1 & 1.2 & 98.80 \\
\hline$-125-+90$ & 28.43 & 28.43 & 29.63 & 70.37 \\
\hline$-90-+63$ & 19.24 & 19.24 & 48.87 & 51.13 \\
\hline-63 & 51.13 & 51.13 & 100 & 0.00 \\
\hline
\end{tabular}

Calculation 6:

If $125(\mu \mathrm{m})=98.80 \%$

$\mathrm{x}(\mu \mathrm{m}) \quad=80 \%$

$x=\underline{80 \times 125}$

98.80

$=101.21 \mu \mathrm{m}$ at $80 \%$

Bond's equation states that

$\mathrm{W}=\mathrm{Wt}=$ Wir $[\underline{10}-\underline{10}]=$ Wit $[\underline{\mathrm{W}}-\underline{\mathrm{W}}]$

$[\sqrt{\mathrm{Pr}} \sqrt{\mathrm{Fr}}] \quad[\sqrt{\mathrm{Pt}} \sqrt{\mathrm{FF}}] \quad$ (Bond, 1952)

Therefore, 


$$
\begin{aligned}
\text { Wit } \left.=\text { Wir } \frac{[10}{10}-\underline{10}\right] \\
\frac{[\sqrt{\mathrm{Pr}} \sqrt{\mathrm{Fr}}]}{[\underline{\mathrm{W}}-\underline{\mathrm{W}}]} \\
{\left[\frac{\sqrt{\mathrm{Pt}}}{\sqrt{\mathrm{Ft} t}]}\right.}
\end{aligned}
$$

where, Wir= work index of the reference ore

Wit $=$ work index of test ore

$\mathrm{Pr}=$ The diameter of the reference ore product, $80 \%$ of which passes through $100 \mu \mathrm{m}$ aperture.

$\mathrm{Pt}=$ The diameter of the test ore product, $80 \%$ of which passes through $100 \mu \mathrm{m}$ aperture.

$\mathrm{Fr}=$ The diameter of the reference ore feed, $80 \%$ of which passes through $100 \mu \mathrm{m}$ aperture.

$\mathrm{Ft}=$ The diameter of the test ore feed, $80 \%$ of which passes through $100 \mu \mathrm{m}$ aperture.

$\mathrm{Wr}=$ work input in kilowatt hour/ short ton for reference ore and

$\mathrm{Wt}=$ work input in kilowatt hour /short ton for test ore

Considering marble as reference mineral,

$\mathrm{Ft}=111.23 \mu \mathrm{m}$

$\mathrm{Fr}=136.35 \mu \mathrm{m}$

$\mathrm{Pt}=101.21 \mu \mathrm{m}$

$\operatorname{Pr}=111.73 \mu \mathrm{m}$

$$
\begin{aligned}
& \text { Wit }=\frac{\operatorname{Wir}(10 / \sqrt{ } \operatorname{Pr}-10 / \sqrt{ } F r)}{\operatorname{Wit}(10 / \sqrt{ } \operatorname{Pt}-10 / \sqrt{ } F r)} \\
& =12,74 \frac{(10 / 111.73-10 / \sqrt{ } 136.35)}{(10 / \sqrt{ } 101.21-10 / \sqrt{ } 111.23)}
\end{aligned}
$$

$=24.92 \mathrm{Kwh} / \mathrm{s}$ ton

Considering granite as reference mineral,

$$
\begin{aligned}
& \mathrm{Pt}=101.21 \mu \mathrm{m} \\
& \mathrm{Ft}=111.23 \mu \mathrm{m} \\
& \mathrm{Fr}=117.9 \mu \mathrm{m} \\
& \operatorname{Pr}=103.52 \mu \mathrm{m} \\
& \text { Wit }=\underline{\operatorname{Wir}(10 / \sqrt{\operatorname{Pr}}-10 / \sqrt{ } \mathrm{Fr})} \\
& \text { Wit }(10 / \sqrt{ } \mathrm{Pr}-10 / \sqrt{ } \mathrm{Fr}) \\
& =15,13(10 / 103.52-10 / \sqrt{ } 117.9) \\
& (10 / \sqrt{ } 101.21-10 / \sqrt{ } 111.23) \\
& =20.39 \mathrm{Kwh} / \mathrm{s} \text { ton }
\end{aligned}
$$


The work index of $20.39 \mathrm{Kwh} / \mathrm{s}$ ton value obtained when granite was a reference ore is within the limit of work index of some iron ores in Nigeria (Weiss, 1965 and Thomas, 2007).

\section{CONCLUSION AND RECOMMENDATIONS}

The study shows that work index of Birnin -Gwari iron ore can be taken as $28.66 \mathrm{Kwh} / \mathrm{ston}$ i.e. $20.39 \mathrm{Kwh}$ of energy is required to reduce one ton of Birnin- Gwari iron ore from $80 \%$ passing.

It is hereby recommended that the value of work index obtained in this study should serve as a guide for designing grinding plant for Birnin- Gwari iron ore in northern Nigeria.

\section{REFERENCES}

Battey M.H (1981): Mineralogy for Students, Longman Inc., New York, pp 91, 159-263. Berry T.F and Bruce R.W (1966): A simple method of determining the grindability of ores, Canadian Mining Journal (July).

Bond F.C (1952), The third law of communition, Trans AIME 193.

Geological Survey of Nigeria (1980): The Geology of Part of South Western Nigeria Bulletin No 31 Vol 26. pp.1-47.

Magdalimovic N.M (1989): Calculation of energy required for grinding in a ball mill, Journal of Mineral Processing 25, (Jan) 41.

One mine (2010): Summary and Determination of the Bond Work index using an ordinary Laboratory Batch Ball mill,http;//www.onemine.org/search/summary.cmf

Thomas D.G (2002): Beneficiation of the Totomuro Iron Ore Deposit, M.Sc Thesis, Department of Metallurgical Engineering, A.B.U, Zaria (unpublished).

Weiss N.L (1985): Mineral Processing handbook by American Institute of Mining, Metalurgical and Petroleum Enginering Incorporated, Kingsport Press,New York. 